\section{Age and significance of alluvium in the Windrush Valley}

RECENTLY Hazelden and Jarvis ${ }^{1}$ reported a radiocarbon date of $2,660 \pm 85$ yr BP for in situ roots in the gravel underlying the alluvium of the River Windrush, Oxfordshire. They suggest that this date represents the regional onset of clay deposition following forest clearance. This hypothesis discounts the possible role of channel migration which, although mentioned by the authors, was not discussed further.

Many rivers in southern and eastern England have gravel underlying the floodplain. Such rivers include the Trent, Nene, Great Ouse and Thames, together with many of their tributaries. The underlying gravels are continuous with those gravels lying about $1 \mathrm{~m}$ above the floodplain, forming the first or floodplain terrace. The majority of these first-terrace gravels seem to be middle-late Devensian in age $^{2}$, and they represent a phase of aggradation probably caused by increased sediment load during periglacial conditions. As sediment supply decreased, when periglacial conditions ended, downcutting occured, giving rise to the wide channel now infilled by alluvium.

Deposition of fine-grained alluvium would be expected to have started as the ameliorating climate led to the formation of meandering rather than braided rivers. Dates from the base of the alluvium are highly variable, ranging from 10,000 to 2,500 yr BP (refs 3,4) and probably reflect the time at which the floodplain deposits were last reworked by a migrating meander rather than an ubiquitous change in conditions.

The deposits of the River Windrush ${ }^{1,5}$ are very similar to those found elsewhere and it therefore seems entirely plausible that an alder tree, growing through a preexisting floodplain with roots in the underlying gravel, should have been eroded by a migrating meander at $2,660 \mathrm{yr}$ BP with no change in sediment supply, climate or base level.

\section{R. D. WILMOT}

Department of Geology,

Imperial College,

London SW7 2BP, UK
HAZELDEN AND JARVIS REPLYWhile this is a possible alternative explanation, it seems to us a less likely one. The truncation of the alder roots is associated with the gravel/clay interface; nowhere in the area have we seen the roots in the clay. Buried A horizons are common within the clay alluvium, and the sequence of deposits is the same over a large area of the floodplain, so it seems that extensive reworking by migrating meanders has not taken place. In view of this and the corroborative evidence from Farmoor we think our explanation more likely.

J. HAZELDEN M. G. JARVIS

Rothamsted Experimental Station, Harpenden,

Herts AL5 2JQ, UK

\section{Trace metals in remote Arctic snows: natural or anthropogenic?}

NRIAGU" states that "It is encouraging that the ratios of the 1901-10 to the 197180 emissions of metals calculated from the data in Table 3 are consistent with the historical changes in rates of trace metal deposition observed in polar ice cores in the Northern Hemisphere". Some of the data cited ${ }^{2-4}$ in support cannot now be considered reliable, and we believe that the remaining data do not support his statement. The historical changes observed in polar ice cores appear much smaller than corresponding changes in worldwide anthropogenic emissions presented by Nriagu in Table 3 .

The rate of trace metal deposition is a complex function of many variables, predominantly that of the deposition rate of snow. Reported deposition rates have been calculated from observed metal concentrations and from accumulation rates of snow which have not apparently changed significantly during the period in question. There is no established theoretical or empirical relationship linking concentrations of metals in precipitation to those in air $^{5}$, but most workers have assumed that the relative abundance of metals in snow reflects the composition of aerosols. Whilst this has been substantiated at the South Pole ${ }^{6,7}$, recent work has revealed considerable differences in composition between Arctic aerosol and snow at Barrow, Alaska ${ }^{8}$.

Of the data cited by Nriagu, results obtained from a temperate glacier in Norway ${ }^{4}$ contain insufficient information about the local geology and analytical procedures, so that the abnormally high metal concentrations quoted must be treated with caution. The Dye- 3 data $^{2}$ for recent snow are now believed ${ }^{3.9}$ to reflect local contamination from the nearby base manned since 1959. Using the data from Camp Century ${ }^{2}$ and Station Milcent ${ }^{3}$, the ratios of metal concentrations in snow deposited during the periods pre- 1900 and post-1960 have been calculated. These values, together with their standard deviations, are given in Table 1. Average concentrations in snow rather than ranges have been considered since the spread of extreme values may in part arise from seasonal variations ${ }^{10}$ and maximum values often represent- contamination. The resulting ranges are so wide that no meaningful conclusion can be made.

Table 1 shows that the concentration ratios in snow are considerably smaller than the corresponding anthropogenic emission ratios. These discrepancies can be partially explained if the natural emissions quoted as most acceptable by Nriagu are added to the anthropogenic emission figures (last column of Table 1). There is even closer agreement if higher natural emission values (within the limits of values given by Nriagu and others ${ }^{11}$ ) are chosen. It is to be expected that a higher proportion of trace elements of natural origin (particularly volcanogenic) will be transported long distances compared with emissions of anthropogenic origin, a major proportion of which return to Earth (Geological Society of London, Spec. Rep. no. 4., 1973).

3. Dury, G. H. US Geol. Surv. Prof. Pap. 452B (1964).

4. Castleden, R. Mercian Geol. 6, 33-48 (1976).

5. Geology of the Country Around Witney (Memoir Geological Survey, GB, 1946).

Table 1 Comparison of global metal emission data with metal concentrations in Greenland snow

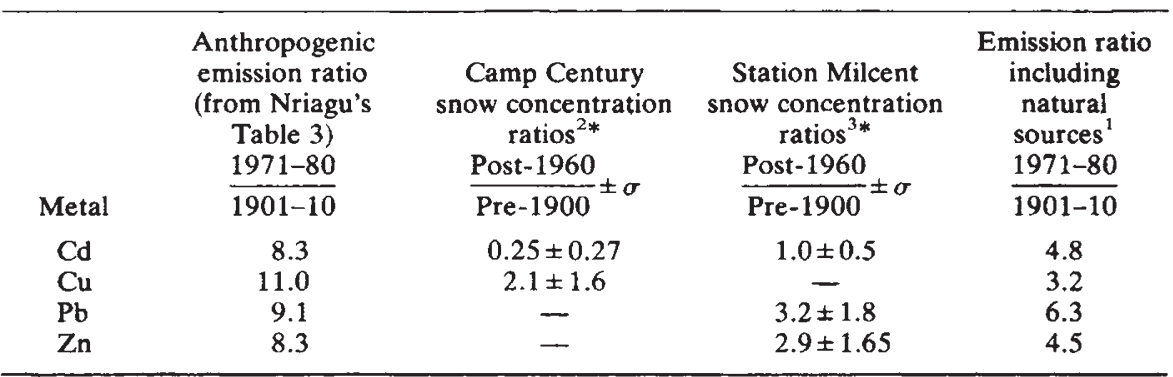

* From averages of metal concentrations in snows. 